\title{
Editorial
}

\section{A parceria entre o CREFITO - 3 e a Revista de Terapia Ocupacional da USP: um novo horizonte de qualificação e crescimento para a produção e divulgação científica em Terapia Ocupacional}

\author{
Elisabete Ferreira Mângia ${ }^{1}$ \\ Marta Carvalho de Almeida ${ }^{1}$ \\ Selma Lancman ${ }^{1}$
}

É com grande satisfação que partilhamos com nossos leitores a efetivação do convênio entre o CREFITO- 3 e a nossa revista, por meio do qual será possível oferecer a edição de três anos do periódico em acesso on-line, através do site do CREFITO-3. A oferta de acesso livre aos volumes da Revista, dos anos de 2004, 2005 e 2006, para os profissionais e estudantes interessados representa um avanço fundamental para a promoção e divulgação da produção científica e pode representar estímulo para a circulação e produção científica da área em todo o país. O apoio torna também possível a ampliação da visibilidade da Revista e de sua circulação internacional, especialmente nos países de língua portuguesa e espanhola.

A consolidação da parceria contou com o apoio integral da diretoria atual do CREFITO-3 e foi construída num clima de confiança e expectativas positivas sobre os novos caminhos a serem trilhados pela Terapia Ocupacional, na busca de sua consolidação científica. Ressaltamos que essa importante possibilidade de trabalho e aprimoramento foi aberta pela luta daqueles que construíram o processo de mudança e transformação do CREFITO-3, sem a qual nada disso seria possível.

Para nós, editoras da Revista, esta nova possibilidade garante a continuidade de nosso trabalho e ainda propicia a oportunidade de investirmos na melhoria da qualidade e qualificação da Revista, que hoje representa uma condição fundamental para nossa permanência no sistema 
de Pós-Graduação. Atualmente, a existência de periódicos nacionais indexados em bases de dados nacionais e internacionais propicia a identificação do status científico da área e possibilita seu reconhecimento pelas demais áreas do conhecimento, além de ser um critério fundamental exigido pelo sistema de implantação e avaliação da Pós-Graduação no país.

Com o apoio do Crefito 3 poderemos, além de garantir a periodicidade de publicação em meio impresso, referente aos anos de 2005 e 2006, e melhorarmos sua qualificação nas bases de dados, organizarmos oficinas de trabalho e cursos, dirigidos aos pesquisadores da área, no sentido de contribuirmos com recursos técnicos e metodológicos para o estímulo à produção de projetos de pesquisa e artigos científicos.

Além de tudo isso, temos claro que, se até aqui viemos viabilizando a Revista de forma semiartesanal e extremamente dependente de nosso esforço pessoal, quase uma militância, hoje nos responsabilizamos pela construção de uma transição que colocará a produção e a reprodução do periódico, cada vez mais, num contexto de maior profissionalização e responsabilização diante das novas exigências avaliativas que temos tentado acompanhar e responder.

Esperamos também, que esse trabalho, quase sempre solitário, possa ser crescentemente compartilhado com os colegas de todo o Brasil. Aos muitos colegas que já vêm contribuindo com esse esforço, pois a revista vem sendo mais e mais alimentada pela produção de inúmeros autores, gostaríamos de manter o convite para que continuem conosco, construindo esse projeto e que possam também, contribuir no envolvimento de novos atores/autores da Terapia Ocupacional brasileira.

Finalmente gostaríamos de expressar nosso reconhecimento e agradecimento a toda a diretoria e grupo de trabalho do CREFITO-3 e especialmente ao seu presidente Dr. Gil Lúcio Almeida, que manteve conosco um diálogo pessoal e solidário. 